\title{
DAMPAK KEBERADAAN PERKEBUNAN SAWIT KALTIM LESTARI TERHADAP PENDAPATAN MASYARAKAT DESA SABINTULUNG KECAMATAN MUARA KAMAN
}

\section{THE IMPACT OF THE EXISTENCE OF KALTIM LESTARI OIL PLANTATION ON COMMUNITY INCOME IN SABINTULUNG VILLAGE, KECAMATAN MUARA KAMAN}

\author{
Mahmud Syamsuddin *1, Wartomo ${ }^{1}$, Elisa Herawati ${ }^{1}$ \\ ${ }^{1}$ Politeknik Pertanian Negeri Samarinda, Kampus Gunung Panjang, Jl. Samratulangi, \\ Samarinda, Indonesia \\ mahmudsyamsuddin4@gmail.com
}

\begin{abstract}
With the existence of the oil palm company PT. Sawit Kaltim Lestari is intended to create jobs, expand job opportunities and business opportunities. Based on this, the oil palm company has a strategic meaning, which is expected to increase community income, support the balance of the economic structure and create and expand employment.

Based on the explanation above, the problem in this study is how the impact of the establishment of the oil palm company PT. Sawit Kaltim Lestari towards community income in Sabintulung Village, Muara Kaman District.

Then this study aims to determine the impact of the establishment of the oil palm company PT. Sawit Kaltim Lestari on community income in Sabintulung Village, Muara Kaman District
\end{abstract}

Key words: impact, income, oil palm

\section{PENDAHULUAN}

Indonesia merupakan negara agraris, dimana pertanian memegang peranan penting dalam perekonomian nasional. Sektor pertanian merupakan sektor yang cukup kuat dalam menghadapi goncangan krisis ekonomi dan dapat diandalkan dalam pemulihan perekonomian nasional.

Kelapa sawit sebagai salah satu komoditi andalan perkebunan Indonesia memiliki peluang besar untuk dikembangkan sebagai penghasil devisa. Hasil olahan dari kelapa sawit yang diekspor adalah minyak sawit kasar Crude Palm Oil (CPO), minyak inti sawit Palm Kernel Oil (PKO), inti sawit Palm Kernel (PK). Jumlah nilai ekspor minyak sawit Indonesia pada tahun 2014 terhadap nilai ekspor non migas mencapai 8 persen atau sebesar 54 milyar dolar Amerika (Suharto, 2006). Perkebunan kelapa sawit merupakan perkebunan yang cukup potensial untuk dikembangkan di Indonesia.
Selain itu dengan adanya perusahaan perkebunan sawit PT. Sawit Kaltim Lestari dimaksudkan untuk menciptakan lapangan kerja, memperluas kesempatan kerja dan kesempatan usaha. Berdasarkan hal tersebut, maka perusahaan kelapa sawit memiliki arti strategis yaitu diharapkan dapat meningkatkan pendapatan masyarakat, mendukung keseimbangan struktur ekonomi serta menciptakan dan memperluas lapangan kerja.

Berdasarkan pemaparan diatas maka yang jadi permasalahan dalam penelitian ini adalah bagaimana dampak berdirinya perusahaan kelapa sawit PT. Sawit Kaltim Lestari terhadap pendapatan masyarakat di Desa Sabintulung, Kecamatan Muara Kaman?

Penelitian ini bertujuan untuk mengetahui dampak berdirinya perusahaan perkebunan sawit PT. Sawit Kaltim Lestari terhadap pendapatan masyarakat di Desa Sabintulung, Kecamatan Muara Kaman Manfaat penelitian ini adalah sebagai berikut : 
1. Sebagai informasi terhadap tingkat pendapatan masyarakat sebelum dan sesudah berdirinya perusahaan perkebunan sawit PT.Sawit Kaltim Lestari.

2. Sebagai referensi bagi mahasiswa yang akan melakukan penelitian yang masih berhubungan dengan penelitian ini.

3. Hasil penelitian ini diharapkan menjadi masukan bagi pihak-pihak yang berkepentingan.

Untuk membatasi penelitian ini maka ditentukan ruang lingkup penelitian yaitu dampak keberadaan perkebunan sawit terhadap pendapatan masyarakat desa Sabintulung.

\section{METODOLOGI}

\section{Tempat Dan Waktu Penelitian}

Penelitian ini dilakukan di Desa Sabintulung, Kecamatan Muara Kaman pada Bulan September 2019 sampai Januari 2020

\section{Alat, Bahan dan Obyek}

Alat yang digunakan dalam penelitian ini yakni kamera handphone, kalkulator, dan alat tulis. Bahan yang digunakan yaitu kuisioner dan yang menjadi obyeknya adalah responden yang telah menetap di Desa Sabintulung minimal 3 tahun sebelum dan sesudah perusahaan berdiri

\section{Prosedur Penelitian}

1. Persiapan atau Orientasi

a. Mengambil data skunder yaitu memperoleh data Kartu Keluarga dan Pekerjaan masyarakat di Desa Sabintulung

b. Survey menentukan obyek

2. Perlakuan

a. Perlakuan yang digunakan saat penelitian yaitu analisis pendapatan masyarakat Desa Sabintulung sebelum dan sesudah perusahaan ada

b. Membandingkan besarnya pendapatan yang kemudian dikonfersikan kedalam bentuk beras dengan rumus : $x=$ $\frac{x 1+x 2+x 3}{\text { harga beras }}$ : jumlah responden c. Pengambilan sampel menggunakan metode purposive sampling. Menurut Arikunto (2010:134-185) apabila populasi penelitian kurang dari 100 maka sampel yang diambil semuanya, namun apabila lebih dari 100 maka sampel dapat diambil sebesar $10-25 \%$ dari jumlah Kartu Keluarga yang telah menetap minimal 3 tahun sebelum dan sesudah berdirinya perusahaan di Desa Sabintulung

d. Kegiatan dilapangan

1. Memberikan kuisioner kepada Kepala Keluarga sebagai responden yang terpilih menjadi sampel

2. Merekap hasil dari kuisioner yang sudah di bagikan

3. Melihat tingkat kesejahteraan masyarakat Desa Sabintulung dengan cara mengetahui harga beras

\section{Analisis Data}

Analisis data yang digunakan dalam penelitian ini adalah analisis deskriptif kuantitatif. Menurut Sugiyono (2005) menyataakn bahwa metode deskriptif adalah suatu metode yang digunakan untuk menggambarkan atau menganalisis suatu hasil penelitian tetapi tidak digunakan untuk membuat kesimpulan yang lebih luas.

Untuk pendekatan penelitian ini menggunakan metode penelitian kuantitatif, seperti yang dikemukakan Sugiyono (2007) bahwa metode yang berdasarkan pada filsafat positivisme, digunakan untuk meneliti pada populasi, atau sampel tertentu yang bersifat kuantitatif/statistik.

\section{HASIL DAN PEMBAHASAN}

\section{Hasil}

Sumber Mata Pencaharian

a. Sumber Mata Pencaharian Sebelum Adanya Perusahaan Perkebunan Sawit PT. Sawit Kaltim Lestari

Sumber mata pencaharian masyarakat di Desa Sabintulung 
sebelum adanya perusahaan perkebunan sawit PT. Sawit Kaltim Lestari, pada umumnya adalah petani maupun buruh. Untuk mengetahui jenis aktivitas ekonomi responden Desa Sabintulung sebelum adanya perusahaan perkebunan sawit PT. Sawit Kaltim Lestari dapat dilihat pada Tabel 1 berikut:

Tabel 1. Sumber Mata Pencaharian Responden Di Desa Sabintulung Sebelum Adanya Perusahaan Perkebunan Sawit PT. Sawit Kaltim Lestari

\begin{tabular}{llll}
\hline No & Sumber Mata Pencaharian & Responden & Persentase (\%) \\
\hline 1. & PNS & 4 & 8,5 \\
2. & Pedagang & 8 & 17 \\
3. & Petani & 19 & 40,5 \\
4. & Buruh & 16 & 34 \\
\hline Jumlah & & 47 & 100 \\
\hline
\end{tabular}

Sumber : Data Primer, Olahan 2020

Nampak bahwa sebagian besar responden sebelum adanya perkebunan sawit berfrofesi sebagai buruh dan petani yakni sebanyak 16 orang atau $34 \%$ menjadi buruh, dan responden yang memiliki aktivitas ekonomi sebagai petani sebanyak 19 orang atau $40,5 \%$, selanjutnya yang memiliki aktivitas ekonomi sebagai pedagang dan PNS yaitu pedagang 8 orang atau $17 \%$, PNS 4 orang atau $8,5 \%$.

b. Sumber Mata Pencaharian Sesudah Adanya Perusahaan Perkebunan Sawit PT. Sawit Kaltim Lestari

Adanya perusahaan kelapa sawit sudah dapat dipastikan akan membuka lapangan kerja dan lapangan usaha, baik langsung maupun tidak langsung, khususnya di Desa Sabintulung karena dapat memperbaiki keadaan perekonomian masyarakat, dimana pada saat sebelum adanya perusahaan kelapa sawit masyarakat banyak yang bekerja sebagai petani dan ada pula yang merantau keluar daerah untuk mencari pekerjaan, namun sesudah adanya perusahaan kelapa sawit masyarakat yang tadinya merantau banyak yang kembali ke kampung halaman untuk berkerja diperusahaan PT. Sawit Kaltim
Lestari. Berdasarkan hasil wawancara dengan warga setempat mereka bekerja sebagai pedagang dan penyedia jasa dan lain-lain yang semuanya itu untuk memenuhi kebutuhan para pekerja perkebunan. Dengan adanya sumber mata pencaharian itu tentu saja akan membuat mereka betah tinggal di kampung halaman serta dengan meningkatnya jumlah karyawan dapat merubah keadaan perekonomian responden ke arah yang lebih baik dibanding sebelum adanya perusahaan perkebunan kelapa sawit PT. Sawit Kaltim Lestari.

Berdasarkan dari hasil penelitian sumber mata pencaharian responden di Desa Sabintulung telah bergerak kearah pedagang. Dimana reponden telah mendapatkan pekerjaan yang nantinya akan merubah aktivitas masyarakat kearah yang lebih baik dan akan mendapatkan pendapatan yang lebih besar dibanding dengan sebelum ada perusahaan perkebunan kelapa sawit PT. Sawit Kaltim Lestari. Untuk lebih jelasnya aktivitas ekonomi yang dilakukan oleh responden dalam penelitian ini dapat dilihat pada Tabel 2 berikut : 
Tabel 2. Sumber Mata Pencaharian Responden Di Desa Sabintulung Sesudah Adanya Perusahaan Perkebunan Sawit PT. Sawit Kaltim Lestari

\begin{tabular}{|c|c|c|c|}
\hline No & Sumber Mata Pencaharian & Responden & Persentase (\%) \\
\hline 1. & PNS & 4 & 8,5 \\
\hline 2. & Pedagang & $15(+7)$ & 32 \\
\hline 3. & Petani & $16(-3)$ & 34 \\
\hline 4. & Buruh & $12(-4)$ & 25,5 \\
\hline Jumlah & & 47 & 100 \\
\hline
\end{tabular}

Sumber : Data Primer, Olahan 2020

Setelah adanya perusahaan kelapa sawit banyak diantara mereka yang bekerja sebagai Pedagang dan petani yakni sebanyak 14 orang atau $32 \%$, dan responden yang memiliki aktivitas ekonomi sebagai petani sebanyak 16 orang atau $34 \%$, selanjutnya yang memiliki aktivitas ekonomi sebagai buruh dan PNS yaitu buruh 12 orang atau $25,5 \%$, untuk PNS 4 orang atau sebesar $8,5 \%$. Demikian dapat disimpulkan adanya pergeseran profesi karena mungkin profesi sebagai pedagang lebih menguntungkan.

Selain besaran jumlah pendapatan pada masing-masing rumah tangga petani kelapa sawit, hal yang perlu dicermati dalam mengamati dampak pelaksanaan investasi perkebunan adalah timbulnya usaha-usaha baru yang dikelola oleh masyarakat. Kegiatan usaha tersebut pada dasarmya merupakan upaya pemanfaatan peluang usaha yang tercipta sebagai akibat adanya mobilitas penduduk, baik yang terpengaruh secara langung maupun sebagai akibat usaha yang tercipta oleh adanya pengaruh tidak langsung usaha yang tercipta oleh adanya pengaruh tidak langsung dari pembangunan perkebunan yang memungkinkan terbukanya peluang usaha lainnya.

Suatu peluang usaha akan menjadi sumber pendapatan yang memberikantambahan penghasilan kepada mayarakat jika mampu menangkap peluang usaha yang potensial dikembangkan menjadi suatu kegiatan usaha yang nyata. Dengan demikian kemampuan masyarakat memanfaatkan peluang yang ada akan dipengaruhi oleh kemampuan masyarakat dalam menangkap peluang itu sendiri.

Walaupun tidak semua kegiatan perkebunan memberikan atau menyebabkan timbulnya sumber-sumber pendapatan bagi mayarakat, namun tergantung kepada jenis investasi perkebunan dan sektor ekonomi yang akan dilakukan. Investasi tersebut pada akhirnya akan berpengaruh kepada seberapa besar manfaat kegiatan perkebunan memberi dampak pada mayarakat sekitarnya. Kebijaksanaan pemerintah dan kemampuan masyarakat dalam memperoleh manfaat dari adanya pembangunan perkebunan sangat berpengaruh. $\mathrm{Hal}$ ini akan menetukan variasi sumber-sumber pendapatan yang akan muncul kemudian.

\section{Pendapatan Responden}

a. Pendapatan Responden Sebelum Adanya Perusahaan Perkebunan Sawit PT. Sawit Kaltim Lestari

Pendapatan merupakan nilai bersih penerimaan yang diperoleh responden dari hasil usaha yang dilakukan baik sebagai petani, buruh, pedagang maupun lainnya. Hasil penelitian menunjukkan bahwa sebelum adanya perusahaan perkebunan sawit PT. Sawit Kaltim Lestari, pendapatan yang diperoleh responden masih tergolong rendah, untuk lebih jelasnya ditampilkan pada Tabel 3 berikut : 
Tabel 3. Rata-Rata Jumlah Pendapatan Responden Desa Sabintulung Sebelum Berdirinya Perusahaan Perkebunan Kelapa Sawit PT. Sawit Kaltim Lestari

\begin{tabular}{cccc}
\hline No & $\begin{array}{c}\text { Rata-rata Pendapatan } \\
\text { (Rp/Bulan) }\end{array}$ & $\begin{array}{c}\text { Jumlah } \\
\text { Responden }\end{array}$ & Persentase (\%) \\
\hline 1. & 1.250 .000 & 26 & 55,3 \\
2. & 1.750 .000 & 12 & 25,5 \\
3. & 2.250 .000 & 9 & 19,2 \\
4. & $>3.000 .000$ & - & - \\
\hline & Jumlah & 47 & 100 \\
\hline
\end{tabular}

Sumber : Data Primer, Olahan 2020

Tabel 5. Nampak bahwa sebagian besar responden masih tergolong berpendapatan rendah yaitu sejumlah 26 orang atau $55,3 \%$ berpendapatan ratarata sebesar Rp.1.250.000 perbulan. Responden yang mempunyai pendapatan Rp. 1.750 .000 sebanyak 12 responden atau $25,5 \%$, sedangkan yang berpenghasilan Rp.2.250.000 sebesar 9 orang atau $19,2 \%$. Bila melihat data-data di atas kondisi perekonomian reponden yang pada umunya bermata pencaharian sebagai petani tradisional yang bergantungan kepada alam yang sangat tinggi menyebabkan aktivitas, dimana waktu lebih banyak terbuang percuma sehingga perubahan ekonomi terkesan begitu lambat.

b. Pendapatan Responden Sesudah Adanya Perusahaan Perkebunan Kelapa Sawit PT. Sawit Kaltim Lestari Pada bagian awal telah dikemukakan mengenai jumlah pendapatan yang diperoleh masyarakat sebelum perusahaan perkebunan kelapa sawit PT. Sawit Kaltim Lestari. Berdasarkan data yang diperoleh bahwa pendapatan responden di Desa Sabintulung umumnya di atas rata-rata dan mengalami peningkatan sesudah adanya perusahaan perkebunan kelapa sawit PT. Sawit Kaltim Lestari, hal ini disebabkan karena selain pendapatan pokok responden meningkat mereka juga mempunyai pendapatan lain dari pekerjaan sampingan yang lebih menguntungkan. Pekerjaan sampingan yang dimaksud seperti pedagang serta masih banyak jasa-jasa lainnya yang dibutuhkan oleh para karyawan. Untuk lebih jelasnya rata-rata jumlah pendapatan responden sesudah adanya perusahaan perkebunan kelapa sawit PT. Sawit Kaltim Lestari dapat dilihat pada Tabel 6 berikut :

Tabel 6. Rata-Rata Jumlah Pendapatan Responden Sesudah Adanya Perkebunan Kelapa Sawit PT. Sawit Kaltim Lestari

\begin{tabular}{cccc}
\hline No & Rata-rata Pendapatan (Rp/Bulan) & $\begin{array}{c}\text { Jumlah } \\
\text { Responden }\end{array}$ & Persentase (\%) \\
\hline 1. & 1.250 .000 & - & - \\
2. & 1.750 .000 & 16 & 34 \\
3. & 2.250 .000 & 20 & 42,6 \\
4. & 5.400 .000 & 11 & 23,4 \\
\hline & Jumlah & 47 & 100 \\
\hline
\end{tabular}

Sumber : Data Primer, Olahan 2020

Tabel 6. Menjukkan bahwa ratarata pendapatan responden sesudah adanya perusahaan perkebunan kelapa sawit PT. Sawit Kaltim Lestari mulai meningkat yakni, sebanyak 11 orang atau
23,4\%, memiliki pendapatan diatas Rp. 5.400 .000 per bulan, sedangkan responden yang berpendapatan Rp.1.250.000 per bulan tidak ada sama sekali. 
c. Perbandingan Pendapatan

Masyarakat sebelum dan sesudah adanya perkebunan kelapa sawit jika di konversikan kedalam bentuk beras

Pendapatan sebelum adanya perusahaan perkebunan sawit apabila dikonversikan kedalam bentuk beras yakni : $x=\frac{x 1+x 2+x 3}{3.000}$ dimana Rp.3.000 itu adalah harga beras pada tahun 2000. Jadi $x=\frac{32.500 .000+21.000 .000+20.250 .000}{3.000}=$ $24.583 \mathrm{~kg}$ beras, jadi per satu KK memperoleh 523,04 kg/bulan. Sedangkan setelah adanya perusahaan perkebunan sawit $x=\frac{x 2+x 3+x 4}{11.500}$ dimana Rp.11.500 adalah harga beras pada tahun 2020, maka hasil yang didapat adalah $x=\frac{28.000 .000+45.000 .000+59.400 .00}{11.500}=$ $11.513 \mathrm{~kg}$ beras, jadi dalam satu KK memperoleh 244,95 kg/bulan.

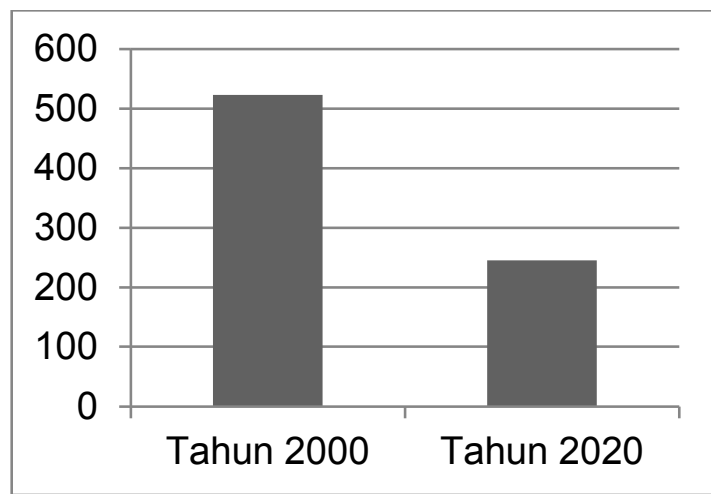

Gambar 1. Perbandingan Pendapatan Masyarakat Jika Dikonversikan Kedalam Bentuk Beras

Pada diagram diatas terlihat pendapatan masyarakat jika dikonversikan kedalam bentuk beras kesejahteraan masyarakat mengalami penurunan yang disebabkan oleh nilai uang terhadap beras lebih tinggi. Sebelum adanya perusahaan perkebunan sawit pendapatan masyarakat jika dikonversikan kedalam bentuk beras sebesar 523,04 kg/bulan dan setelah adanya perusahaan perkebunan sawit sebesar 244,95 $\mathrm{kg} / \mathrm{bulan}$.

\section{HASIL DAN PEMBAHASAN}

Hadirnya perusahaan perkebunan kelapa sawit PT. Sawit Kaltim Lestari di Desa Sabintulung, memberikan dampak terhadap pendapatan masyarakat sekitar, dibandingkan sebelum adanya perusahaan perkebunan kelapa sawit.

Jika dilihat dari sisi ekonomi setelah adanya perusahaan perkebunan sawit terjadi peningatan pendapatan dimana rata-rata pendapatan responden sesudah adanya perusahaan perkebunan kelapa sawit PT. Sawit Kaltim Lestari sebanyak 11 orang atau $23,4 \%$, memiliki pendapatan diatas Rp. 5.400 .000 per bulan, sedangkan responden yang berpendapatan Rp.1.250.000 per bulan tidak ada sama sekali. Pada tabel 6 menunjukan masih terdapat responden yang berada dibawah tingkat garis kemiskinan yang ditetapkan oleh badan pusat statistik, dimana dari 47 responden terdapat 16 responden yang berada dibawah garis kemiskinan, hal ini dipengaruhi oleh faktor sosial.

Apabila pendapatan dikonversikan kedalam bentuk beras pendapatan masyarakat mengalami penurunan setelah adanya perusahaan perkebunan sawit, hal ini dipengaruhi karena nilai uang terhadap beras lebih tingi.

Berdasarkan hasil penelitian terjadi pergeseran jenis aktivitas ekonomi masyarakat dimana sesudah adanya perusahaan perkebunan sawit banyak diantara mereka yang bekerja sebagai Pedagang dan petani yakni sebanyak 14 orang atau $32 \%$, dan responden yang memiliki aktivitas ekonomi sebagai petani sebanyak 16 orang atau $34 \%$.

\section{KESIMPULAN}

Berdasarkan hasil dan pembahasan maka dapat disimpulkan bahwa adanya perusahaan perkebunan PT. Sawit Kaltim Lestari memberikan dampak pada sektor pendapatan.

Sebelum adanya perusahaan perkebunan sawit rata-rata pendapatan dari 47 responden sebesar $R p$. 73.750.000 dan jika dikonversikan 
kedalam bentuk beras sebesar 523,04 $\mathrm{kg} /$ bulan. Sedangkan pada tahun 2020 pendapatan responden sebesar Rp. 132.400.000 dan jika dikonversikan kedalam bentuk beras sebesar 244,95 $\mathrm{kg} / \mathrm{bulan}$.

Apabila dikonversikan kedalam bentuk beras pendapatan responden mengalami penurunan, hal ini disebabkan oleh tingginnya nilai tukar rupiah rehadap beras, pada tahun 2020 harga beras mencapai Rp. 11.500 sedangkan pada tahun 2000 harga beras Rp.3.000.

\section{DAFTAR PUSTAKA}

Arikunto, 2010. Prosedur Penelitian: Suatu Pendekatan Praktek. Jakarta Rineka Cipta

Badan Pusat Statistik (BPS). Garis Kemiskinan Masyarakat. Diakses Dari http://.bps.go.id/, diakses Pada Tanggal 19 Oktober 2020

Boediono, 2000. Ekonomi Moneter, edisi 3, BPFE: Yogyakarta

Moeljianto, 1992. Pengawetan dan Pengolahan Hasil Perikanan. Penebar Swadaya. Jakarta.
Soedharto. 2000. Kapita Selekta Hukum Pidana. Bandung: Citra Aditya Bakti

Soemartono. 2011.Hukum Lingkungan Indonesia. Jakarta: Sinar Grafika

Sugiyono. 2005. Metode Penelitian Bisnis. Bandung: Alfabeta

Sugiyono. 2007. Metode Penelitian Pendidikan Pendekatan Kuantitatif, Kualitatif dan R\&D. Bandung: Alfabeta

Suharto. E. 2006. Membangun Masyarakat Memberdayakan Rakyat. Bandung : PT Refika Aditama

Wahyu. Supriadi Waskito. 2007. Pergeseran Mata Pencaharian Masyarakat Desa, Skripsi : FISIP UNS. Surakarta

Winardi, 1992. Management Perilaku Organisasi, Bandung: Citra Aditya Bakti

Winardi, 2003. Entrepreneur \& Entrepreneurship. Jakarta: Prenada Media 